Vol. 07, No. 03, pp. 1-24, September 2014

\title{
BEHAVIOUR OF RETAINING WALL FOUNDED ON COLLAPSIBLE SOIL - A PROTOTYPE LABORATORY STUDY
}

\author{
Safa Hussain Abid Awn ${ }^{\mathbf{1}}$, Waad Abdulsattar Zakaria ${ }^{2}$ \\ ${ }^{1}$ Lecturer, ${ }^{2}$ Assistant Professor, College of Engineering, Diyala University \\ E-mail: safa_alshamary@yahoo.com ${ }^{1}$, waadzakariya@yahoo.com ${ }^{2}$ \\ (Received: 30/9/2012; Accepted: 26/9/2013)
}

\begin{abstract}
Retaining walls may be required in a location where gypsum may present in soil in large percentages. The behavior of retaining walls on ordinary soils is well known but the behavior of retaining walls resting on gypseons soils may be not well understood as the case of ordinary soils.

In this study it is intended to reflect the behavior of gravity retaining wall resting on collapsible soil. And to do so a small prototype model $(600 \mathrm{~mm} * 500 \mathrm{~mm} * 200 \mathrm{~mm})$ is used with soil mixed in presumed percentages with different gypsum percentages $(5 \%, 20 \%, 30 \%$, $50 \%$ ). In addition to a model with $30 \%$ gypsum and treated with $2.7 \%$ Cement dust mixed with soil founded retaining wall structure. After preparing the foundation gypseous soil, a small glass made retaining wall filled with sand, which represent gravity wall, is put over such bed and backfilled with ordinary sandy soil. Dial gauges are placed to side and top of wall to measure the rotation settlement behavior and collapse of system. $4 \mathrm{kPa}$ stress are applied to backfill soil as to accelerate collapse with leaching process commenced. Data are recorded and analyzed completely, which shows the behavior of such structures embedded with different gypsum content.
\end{abstract}

The improvement in rotation settlement and collapse for the retaining wall model reaches more than $89 \%$, was gained after treating the embedded gypseous soil layer, with $2.7 \%$ cement dust.

Key Words: Retaining wall, Collapsible soil, improvement.

\section{INTRODUCTION}

Now day's real estates are becoming very expensive. Before, in past, if one spot location has soil with bad strength properties, then the solution is to change this location to 
another location with good soil strength properties .This type of solution is not applicable or no more practical in these days. The high expense of estate only leaves the choice of using this ground for the purpose intended with proper improvement or suitable countermeasures so that the existing structure can with stand the behavior of this bad strength soil properties .One of the problems associated with such soil is the presence of collapsible soil or the gypseous soil which is one of the many types of it.

A gravity retaining wall is typically used to form the permanent wall of an excavation wherever space requirement make it impractical or even impossible to simply slope the sides of the excavation. As a matter of fact such situations arise when a road for example or storage area is needed immediately adjacent to an excavation. In order to construct a wall, a temporary slope is formed at the edge of the excavation, wall is built, and then backfill is dumped into the space between wall and the temporary slope. It is worth to mention that in earlier days masonry wall were often used. Today, most walls are of unreinforced concrete although special forms of construction are used. There are other many situation in which many movements of retaining structures must be given serious consideration where consideration of stability only is inadequate for a proper design.

In general, these are two broad categories of retaining structures:

(1) Gravity or freestanding wall, in which stability is due to mainly the weight of the structure.

(2) Embedded walls: in which stability is due to the passive resistance of the soil over the embedded depth and, in most cases, external support. According to the principles of limit state design, an earth - retaining structure must not; (a) collapse or suffer major damage (b) be subjected to unacceptable deformations in relation to its location and function and (c) suffer minor damage which would necessitate excessive maintenance, render it unsightly or reduce its anticipated life. Ultimate limit states are those involving the collapse or instability of the structure as a whole or the failure of one of its components. Serviceability limit states are those involving excessive deformation, loading to damage or loss of function. Both ultimate and serviceability limit states must always be considered.

The design of retaining structure has traditionally been used on the specification of a factor of safety in terms of moments (the ratio of the resisting moment to the over turning moment).This factor of safety is given a value high enough to allow for all uncertainties in the analytical method and in the value of soil parameters. However, it must be recognized that relatively large deformation are required for the mobilization of available passive resistance and that a structure could be deemed to have failed due to excessive deformation before reaching a condition of collapse. 


\section{EXPERIMENTAL WORK:}

In this study it is intended to measure the deformation of a gravity retaining wall resting on collapsible soil. This is done through use a model proto type. Here in this case we may have a large deformation of wall not due to lateral soil thrust only but due to the collapse of soil under retaining wall. The following section illustrates the description of setup used, soil, and results achieved with comprehensive photos and graphs. It is intended, as well to give a perspective picture of the problem since similar problems do exist in Iraq such as the national dam in Mosul which is a huge dam resting on collapsible rocks. Since then continuous grouting in soil under dam is going on to stop or at least reduce the settlement of dam with time. The testing program are shown in figure (1)

\section{Soil Used}

Obtaining undisturbed sample of gypseous soils is in many cases very difficult. This led many researchers to prepare the gypseous soils in the laboratory. The behaviors of gypseous soils in the laboratory highly complicated and different were noted. This caused a conflict in understanding the phenomena related to the gypseous soils (Al-Mufty, 1997).

Choosing soil for the setup prototype is not an easy task and imposes a difficult problem for author for the believed followed reasons, although many other reasons exist as well:

1. Soil used testing should have high coefficient of permeability as to accelerate percolation of water through soil in model. It is obvious that if soil has low coefficient of permeability the time for each test may become impractical to conduct such test. For this purpose author have closer to use sandy soil for the backfill material and same soil mixed with gypsum as to form the base soil for the retaining wall. The classification tests conducted for such soil is summarized in figure (2). It is classified as (Bole Sand) soil.

2. Since this study is concerned with behavior of a retaining wall founded over gypseous soil, the gypseous soil used to simulate the base soil is the fundamental factor controlling the behavior of retaining wall. How to close our gypsum soil? Is related to factors such as the following (believed by authors).

The gypsum proportions are choosing at 5\%,20\%,30\% and 50\% by weight, gypsum soil ratios. It is hoped by author that these large scan of ratios will envision the full scale behavior of gypsum content. High percentages of gypsum content do exist in Iraq such as Tickret and Beijy discrete in the middle-northern region. In these landscapes gypsum content can be found as high as $70 \%$ especially in the near surface soil. It is worth to mention here 
that changing gypsum content in soil is only to reflect the behavior of the retaining wall upon increasing amounts of gypsum in base soil.

\section{Model Prototype Description}

First of all, the prototype is made by author out of $6 \mathrm{~mm}$ sheets of glass. This technique able us to observe very closely the percolation process of water the soil. The dimensions of glass box model are: $600 * 500 * 200 \mathrm{~mm}$. The gravity retaining wall is made of glass to (empty inside). It has a base width of the width of glass box (actually less than width of box by about $5 \mathrm{~mm}$ to allow free movement of wall without any friction or interference with the sides of model. Figures (3) and (4) show the model prototype. The retaining wall (which is made of glass) is filled with sand as to simulate a concrete retaining wall.

\section{Model preparation and Testing Procedure}

Initially the gypsiferous soil is prepared outside the model. Specified weight of dry soil is mixed with specified weight of gypsum as to form a soil with required or intended gypsum content. After mixing soil is given little water (by sprayers action) so that it can receive little compaction in model. The gypsiferous soil is transferred to tank and dumped there in terms of three layers, each of $70 \mathrm{~mm}$ and each layer is given, as said, light compaction reaches $12.3 \mathrm{kN} / \mathrm{m}^{3}$. After that the retaining wall filled with sand, is placed in middle of model, sand without gypsum (pure sandy soil) is poured without compaction is damped as a backfill behind the wall with $11.4 \mathrm{kN} / \mathrm{m}^{3} .4 \mathrm{kPa}$ Surcharge is subjected with the aid of dead weights to simulate some reality. Now the model is ready to be tested and in order to explain comprehensively the step for testing a single model, the method of testing is summarized in the following points. Figures (5) to (6) show model preparation and testing procedure.

1. Since more than forty $\mathrm{kg}$ of soil is put into the model, initially it is placed near a large heavy steel table in order to fine the dial gauge folder to it. After location the glass model near table the preparation for tank is carried out as usual and as said earlier.

2. Two dial gauges are applied (attached to retaining wall), one is place vertically in order to measure the settlement of the wall, and another one is placed horizontally in order to measure the horizontal movement of wall. The two dial gauges are fixed to magnetic holders and in two those are fixed magnetically to the large steel table. 
3. Now initial readings for both dial gauges are recording. These reading are the basic for later and subsequent readings since the settlement and horizontal movements are only the difference reading between "now" reading and initial reading.

4. To start the deformation time behavior, water is poured in the backfill side (behind the wall) and reading with time are simultaneously recorded, so, we have two curve one for vertical settlement of retaining wall and other for horizontal rotation of wall, it is believed that these two curves can describe the movement of wall in two directions.

5. It is customary to normalize the data so that it is well understand in terms of some specified dimension of wall. Thus the vertical settlement is normalized in terms of footing width or wall height $(\mathrm{H})$. So, we have settlement is represented as S/B and wall rotation in terms of $(S h / H)$ where :

$\mathrm{S}=$ Settlement

$\mathrm{B}=$ Width of retaining wall

$\mathrm{Sh}=$ Horizontal movement or rotation

$\mathrm{H}=$ Height of wall

6. The $\mathrm{S} / \mathrm{B}$ and $S h / H$ are plotted with time in which time scale is represented in logarithmic scale and S/B and $S h / H$ are in arithmetic scale.

\section{EXPERIMENTAL RESULTS}

Upon conducting triaxial tests on cohesion less soil, Lamb (1979) show that strained required to achieve active and passive conditions may be inferred from the results of triaxial tests and his important conclusion are:

1- Very little horizontal strains, less than $0.5 \%$ is required to reach the active state.

2- Little horizontal compression, about $0.5 \%$ is required to reach one-half the maximum passive resistance.

3- Much more horizontal compression, about $2 \%$ is required to reach the full maximum passive resistance.

4- The foregoing results are typical for most dense sands. For loose sands the first two conclusions remain valid, but the horizontal compression required to reach full passive resistance may as large as $15 \%$. The results apply where the initial condition is not Ko condition. If initially $\sigma^{\prime} h / \sigma^{\prime} \neq \neq \mathrm{Ko}$, then somewhat different strains will be required to reach the limiting condition and since most field problem involving retaining structures are plane strain situations, the triaxial data are only indicative of those applicable to actual field problems. 
Full scale models were conducted by Terzaghi (1920). He demonstrated the active and passive theories by very careful tests. In these tests the walls were held against horizontal movement as the back fill was placed and the thrust against the wall was measured. The thrust was greater than the active thrust. Then the wall was released and permitted to move horizontally or rotate. After a movement of the top of the wall equal to only 0.001 times the height of wall, thrust was dropped to its theoretical active value. This is very small amount of movement with angular rotation of only 0.06. On the other hand Bowles (1992) presented a table showing amount of horizontal translating to motive to the Ka condition, as shown in table (1).

From the foregone discussion it is intended to compare the movement of retaining wall with standard movement of retaining wall according to ranking and coulomb theories of acting and passive states, i.e., the k., Ka and $\mathrm{Kp}$ conditions of soil. And as said before that careful studies conducted by Terzaghi about one century ago revealed that a horizontal movement of 0.001 times height of wall (a displacement of $0.001 \mathrm{H}$ ) is only enough to show up the Ka condition.

Retaining to our model the first one conduced was by using equal share of gypsum and soil, i.e that is $50 \%$ of gypsum content. A crack in model glass after few hours led to the leakage of all perched water in tank. Never the less we have two figures simulating the movement that is figures (7) and (8). In these figures the displacement of retaining wall is presented in normalized form with time in minutes. The vertical settlement is shown in terms of settlement width of wall.

In figure (7) it can be seen that the total angular rotation wall is 0.00235 from the early start of soaking process and it is above the Terzaghi limit of reaching the Ka condition which is proven to be 0.001 . The final number reached after about one week of soaking process is about 0.0288 which is ten times the rotation needed for soil to be transferred from "at rest" to active state. Thus it is concluded by authors that rotation of retaining wall founded on 50\% gypseous soil, cannot calculated in terms of coulomb and Rankin theories since this movement is not solely due to the active state (although it is included into) but due to as well the collapse settlement of soil below wall. Due to the small (relatively) height of wall, this low rotation is expected (as can be year) although the gypsum content in base soil is considered terribly high.

In figure (8) the vertical settlement of retaining wall quickly increases to about (Sv/B) $\%$ value of 0.027 and remains throughout that level approximately to end of test. At end of test and that is about one week after, uneven movement took place in terms of up and down 
movements in the level $(\mathrm{Sv} / \mathrm{B}) \%$ of 0.027 . This trend of behavior is attributed to uneven collapse settlement of the base gypseous soil with $50 \%$ gypsum content. This could be due to the failure in glass of model which made the process to contain some leaching in addition to soaking process. The water is kept into model no matter how leakage was.

In figure (9) and (10) very low amount of gypsum content is used namely $5 \%$ of soil dry weight. These two extreme boundaries of gypsum content, very high (50\%) and very low (5\%) are taken into account just to simulate actual condition that may encounter a civil engineer, now before going further into discussion, a general look at those two figures shows too much fluctuation in data recording for both horizontal and vertical movements. In order to explain these data, author has resorted to figure (3) which show the retaining wall in isotropic view.

At point A the dial gauge measuring the vertical movement of retaining wall is installed by fixing it to large steel table. At point B the dial gauges measures the horizontal movement of wall is installed and fixed as in the case of the vertical movement. Now if we visualize that tip $\mathrm{C}$ settles alone downwards due to uneven collapse settlement the dial gauge at B will record positive movement of wall while that at tip A may measure zero settlement or may even record an upward movement if the center of rotation is at point between $\mathrm{C}$ and D.

On the other hand, if we have a settlement under point $\mathrm{D}$ only while point $\mathrm{C}$ remains still (again due to uneven settlement) then dial gauge at A may record a positive downward settlement while dial gauge at B may give negative records. In other words, due to uneven and differential collapse of retaining wall these fluctuations in curves of figures (9) and (10) is attributed to the movement of retaining wall under collapse settlement which in turn depends on the location of center of rotation between points $\mathrm{C}$ and $\mathrm{D}$. It is worth to mention here that the foregone explanations agree well with time of fluctuations.

The flection of both $(\mathrm{Sh} \backslash \mathrm{H}) \operatorname{and}(\mathrm{Sv} \backslash \mathrm{B})$, wares with log time, start both at approximately same frame as can be see clearly in figures. So these figures lead to a fact that collapse settlement of retaining wall founded over gypseous soil is totally no uniform and quite differential in nature unlike of most settlements. Its worth to mention that Bowles (1997) stated that convert retaining walls have a tendency to tilt forward because of the lateral earth pressure. But they can also tilt from base rotation caused by differential settlements. Occasionally, the base soil is of poor quality and with placement backfill (typically the approach fill at a bridge abutment) the backfill pressure produces a heel settlement that is greater that at the toe .this difference causes the wall to fill into the backfill as mentioned by Bowles (1997). If the Rankin active earth pressure is to form, it is necessary 
that the wall tilt forward. A wall with a forward tilt does not give an observer much confidence in its safety. Unless the wall has a front batter it is difficult for it to tilt forward even a small amount without the tilt being noticeable. It may be possible to reduce the tilt by overdesigning the stem, say, use ko instated of ka pressure and raise the location of resultant.

figures (9) and (10), shows that the retaining wall begins its movement only after one hour of soaking .after that the wall begin to fluctuate in its horizontal and vertical movement and finally became still at a horizontal tilt of $(\mathrm{Sh} \backslash \mathrm{H})=0.0025$ which is still beyond the ka condition although it reaches a maximum value, during period of fluctuation, of 0.0053 which is about five times the tilt strain required to motivate the ka condition. that small quantity of gypsum content (5\%), can cause tilt action to retaining wall above the ka condition . in other wards a civil engineer should take serious counter measure where thinking in building a retaining wall on such types of problematic soil.

In figure (10) the value of $(\mathrm{Sv} / \mathrm{B})$ begins to settle down after about one hour of soaking process and continues at trend of behavior for about four to five hours then finally levels off at a value 0.025 . This is a rather small value of settlement ratio. In addition, if we consider or take into account a large dimension of (B). This amount of settlement may sum up to be large in terms of dimensions

Another model is built with gypsum content of $20 \%$. The curves versus time for horizontal and vertical movements are shown up in figure (11) and (12). In figure (11) the horizontal movement started to show up drastically after about one day and reaches to a maximum value of 0.0061 in a rather fluctuated. This amount is, as before, six times the movement required for ka condition due to the large base settlement of gypsum soil base .but at lost levels off at a value of $(\mathrm{Sh} / \mathrm{H})$ of 0.0045 after about six days. This residual value is still well beyond the ka value. When we compare time in which retaining wall starts to fluctuate in its movement in figure (9) and figure (10) we see that locate almost same time. in figure (10) which is quite similes to figure (9), we see that after about one day the wall starts to settle down till a maximum value (Sv/B) of 0.01 then finally levels off at a value of 0.0024 this value is rather small but the tilt value is rather high.

Till now author have experienced three percentages of gypsum content, namely, 50\%, $5 \%$, and $20 \%$. It is suggested to complete the vision and make another two tests but with gypsum content of 30 for both models. The second model is mixed with $2.7 \%$ (by dry weight) cement. In this way we may be able to compare between the two models the effect of cement on gypseous soil in case of retaining walls.

Figure (14) shows the vertical movement of retaining wall, while fig. (13) Shows the horizontal movement of wall, and fig. (20) Shows both curves, together. Similarly fig. (15) 
shows the horizontal movement of retaining wall after mixing base soil with $2.7 \%$ with cement, fig. (16) Shows the vertical movement, and figure. (21) Shows both curves together. All curves are drawn as usual versus time in logarithmic scale. May someone think, if there exist a problematic soil, such as a collapsible soil, it is better to replace it than to take it away, improve it by some additions (cement for example) then get it back to original place to be used as a foundation soil. If clear gypsum free soil exists in nearby place, then it is meaningless to improve the gypseous soil by mixing it with cement then get it back in the first place. But what if there is no nearby soil with good engineering properties or no tracks or transporting vehicles available or very expensive to transport to place, then the improvement of local soil is the best choice available at hand. This case is totally reported by Lamb \& Whitman (1979) where a highway was intended to be constructed across desert over saline soil. The good engineering properties soil was available at distance of thousands of kilometers away from position in concern. The choice was made to improve the local sub grade soil by mixing it with $1 \%$ of cement and job was done and completed. Author's feet that same condition may exist if a civil engineer has encountered a case of retaining wall founded on gypseous soil. In other words, the final test conducted does conform to reality, although may be rare, and remembering that local estates are becoming more expensive year by year and the choice of replacing the place with another is no valid today.

Retaining now to our curves, the following numerical values are deduced from those figure are summarized in table (2). They represent the maximum movement recorded for the two cases.

From the initial look at those results it is quite dear that the addition of cement to gypseous soil base has greatly reduced both the horizontal and vertical movements together. The reduction in the maximum $\mathrm{Sh} / \mathrm{H}$ and $\mathrm{Sv} / \mathrm{B}$ after treating gypseous soil below retaining wall by $2.7 \%$ cement addition that are shown in table (2) were obtained from the following formulae.

\%Improvement obtained in settlement $=\frac{(S v / B) u-(S v / B) T}{(S v / B) u} \times 100$

And for tilt

$\%$ Improvement obtained in tilting $=\frac{(S h / H) u-(S h / H) T}{(S h / H) u} \times 100$

Where $\mathrm{u}$ and $\mathrm{T}$ denotes untreated and treated models

The improvement obtained, as can be seen from table (3), is very great and opens a promising future for dealing with gypseous soil. It is worth to mention that the better results 
if desired is through leaching which is not done in this case. Of course, if leaching is included the movement wills definitely increases and thus the improvement obtained will be less.

\section{CONCLUSIONS:}

In this study it is desired to focus on the behavior of ordinary retaining wall founded over gypseous soil. Retaining walls are often used frequently when slope stability limitation stands against suitable or available space .There are many types of such walls. This study provides comprehensive aspects for movements of retaining walls when water percolates through foundation soil. The container is made from glass, in order to monitor the movements of water and retaining wall as well in all testing's. The wall movements are based on active and passive theory and based on the collapse potential of the underneath gypseous soil as it settles when water preclude it gradually. Treatment was made by mixing $2.7 \%$ of cement with gypseous soil together to reduce the vertical and tilting strain of such structure.

Table (4) Summarize the results of prototype models tests of lateral retaining wall constructed on different percentages of collapsible soil:

From this study authors have concluded the following points hopping to be useful for student in concern:

1) Gypseors soils collapse through water percolation with small or large stresses applied .This is a fact reached by so many researchers and well observed by authors through dealing with such soil for first time.

2) Results revealed that the movement of retaining wall through testing's is not uniform .By this, authors mean that retaining wall may fill forward or backward, settles in toe faster than heel or the opposite. The vertical and horizontal movements are totally random, that is due to the uneven settlement of wall resting on gypsies soil.

3) The improvement in rotation settlement and collapse for the retaining wall model reaches more than $89 \%$, was gained after treating the embedded gypseous soil layer, with $2.7 \%$ cement dust.

4) Soil, after test complete, sticks to glass container, thus extracting the old soil tested by new soil set to start a new test was something very difficult authors tried to use nylon layer as a linear to but there was no use of all that.

5) Authors preferred to use laboratory - made gypsified soil rather than bringing natural gypseous soil. The first type, which is called "gypsiferous soil", has the nest of better controlling the gypsum content in soil with same engineering properties but with different percentages of gypsum content. 


\section{RECOMMENDATIONS:}

Author recommends the following points drawn below, hopping to be taken into account in future work:

1- The whole work may be separated but using calcareous or saline soil to make a wider spectrum in studying the behavior of retaining wall resting over many problem tic soils.

2- The use of glass container may be replaced by a steel box with the facility of one or more of its sites be opened easily in order to replace soil easily, similar to steel concrete molds.

3- Different type and shapes of retaining walls may be used as to scan the effect of shape and configuration of retaining wall over collapsible soil.

\section{REFERENCES:}

1. Al-Mufty, A. A. 1997, Effect of Gypsum Dissolution on the Mechanical Behavior of Gypseous soils, Ph.D. thesis Department of Civil Engineering, University of Baghdad.

2. Alphan, J. G. And Romero, F.R. 1971, Gypseous soil, Notes on their characteristics and management, International Institute for land Reclamation and Improvement, Netherland.

3. Barazanji (1973) "the methods of classification the gypseous soil".

4. Bowles, J.E. (1997), (Lateral earth pressure).pp 681-691.

5. Lambe T.W, and Whitman, R.V. 1979, Soil Mechanics, Jhon Wiley and Sons .Inc. New York.

6. Ching, F. D., Faia, R., S., \& Winkel, P. (2006). Building Codes Illustrated: A Guide to Understanding the 2006 International Building Code (Building Codes Illustrated) $(2$ ed $)$. New York, NY: Wiley.

7. (2011) Commercial Installation Manual for Allan Block Retaining Walls (p. 13)

8. Ambrose, J. (1991). Simplified Design of Masonry Structures (pp. 70-75.). New York: John Wiley and Sons, Inc.

9. Crosbie, M. \& Watson, D. (Eds.). (2005). Time-Saver Standards for Architectural Design. New York, NY: McGraw-Hill.

10. Terzaghi, K. (1934), Large Retaining Wall Tests, Engineering News Record Feb. 1, March 8, April 192006 International Building Code Section 1806.1.

11. "Segmental Retaining Walls". National Concrete Masonry Association. 2008 http://web.archive.org/web/20080304073923/http://www.ncma.org/use/srw.html. 
12. Terzaghi, K. (1943), Theoretical Soil Mechanics, New York: John Wiley and Sons

13. Ambrose, J., (1991). Simplified Design of Masonry Structures (pp. 70-75.). New York: John Wiley and Sons, Inc.

14. Bowles, J., (1968). Foundation Analysis and Design, McGraw-Hill Book Company, New York

15. Building Code (Building Codes Illustrated) $\left(2^{\text {ed }}\right)$. New York, NY: Wiley.

16. Ching, F. D., Faia, R., S., \& Winkel, P. (2006). Building Codes Illustrated: A Guide to Understanding the 2006 International

17. Crosbie, M. \& Watson, D. (Eds.). (2005). Time-Saver Standards for Architectural Design. New York, NY: McGraw-Hill.

18. Al-Neami, M. M. (2010), "Improvement of gypseous soil by clinker additive". Eng. And Tech. Journal Vol. 28, No 19.

19. Talal S and Abdullah Sabtan" Geotechnical and Geochemical properties of AlNekhaila Sabkha, south of Jeddah", Journal of king Abd Al-Aziz, Earth Sciences ISSN, 1999, Vol. 11, pp161-176. Publisher KAU-Scientific Publishing Center

20. Valenza, A. and Gillot, J. C. "Influence of groundwater on the degradation of irrigation soils in a semi-arid region, the inner delta of the Niger River, Mali", Hydrology Journal ISSN, 2000, Vol.8, pp. 417-429.

Table (1): Horizontal translating in order to motive to the Ka condition. After Bowles (1992).

\begin{tabular}{|c|c|}
\hline soil and condition & Amount of translating \\
\hline Cohesion less, dense & 0.001 to $0.002 \mathrm{H}$ \\
\hline Cohesion less, loose & 0.002 to $0.004 \mathrm{H}$ \\
\hline Cohesion less, firm & 0.01 to $0.02 \mathrm{H}$ \\
\hline Cohesion less, soft & 0.02 to $0.05 \mathrm{H}$ \\
\hline
\end{tabular}

Table (2): Effect of $2.7 \%$ cements addition, to $30 \%$ gyp. Soil bed below retaining wall model conducted in this study. 


\begin{tabular}{|c|c|c|}
\hline Soil condition & Maximum $(\mathbf{S v} / \mathbf{B})$ recorded & Maximum $(\mathbf{S h} / \mathbf{H})$ recorded \\
\hline $30 \%$ gyp. Soil bed & $1.52 \%$ & $1.15 \%$ \\
without treatment & Or 0.0152 & Or 0.015 \\
\hline $30 \%$ gyp. Soil treated & $0.167 \%$ & 0.86 \\
with 2.7\% cement & Or 0.000167 & Or 0.0086 \\
\hline
\end{tabular}

Table (3): Improvement in vertical settlement and tilt action of retaining wall bedded with $30 \%$ gypseous soil with the addition of $2.7 \%$ cement.

\begin{tabular}{|c|c|c|}
\hline $\begin{array}{c}\text { Improvement of gyp. soil layer } \\
\text { below retaining wall }\end{array}$ & $\begin{array}{c}\text { \% Improvement in } \\
\text { settlement }\end{array}$ & $\begin{array}{c}\text { Improvement in } \\
\text { Tilt action }\end{array}$ \\
\hline $\begin{array}{c}\text { Mixing gyp. Soil with } 2.67 \% \\
\text { cement }\end{array}$ & $89 \%$ & $99 \%$ \\
\hline
\end{tabular}

Table (4): Maximum Values Recorded for lateral retaining wall model constructed on different percentages of collapsible soil.

\begin{tabular}{|c|c|c|}
\hline \multirow{2}{*}{$\begin{array}{c}\text { \% Gyp. Content } \\
\text { Used }\end{array}$} & \multicolumn{2}{|c|}{ Maximum Value Recorded } \\
\cline { 2 - 3 } & $*$ Sv/B \% & $* * S h / H \%$ \\
\hline 50 & 3.28 & 2.88 \\
\hline 5 & 2.75 & 0.53 \\
\hline 20 & 0.99 & 0.61 \\
\hline 30 & 1.52 & 1.15 \\
\hline 30 with 2.7\%cement treatment & 0.29 & 0.88 \\
\hline * Sh/H\% rotation settlement & $* * S v / B \%$ collapse settlement \\
\hline
\end{tabular}

$*$ Sh/H\% rotation settlement. $\quad * * S v / B \%$ collapse settlement 


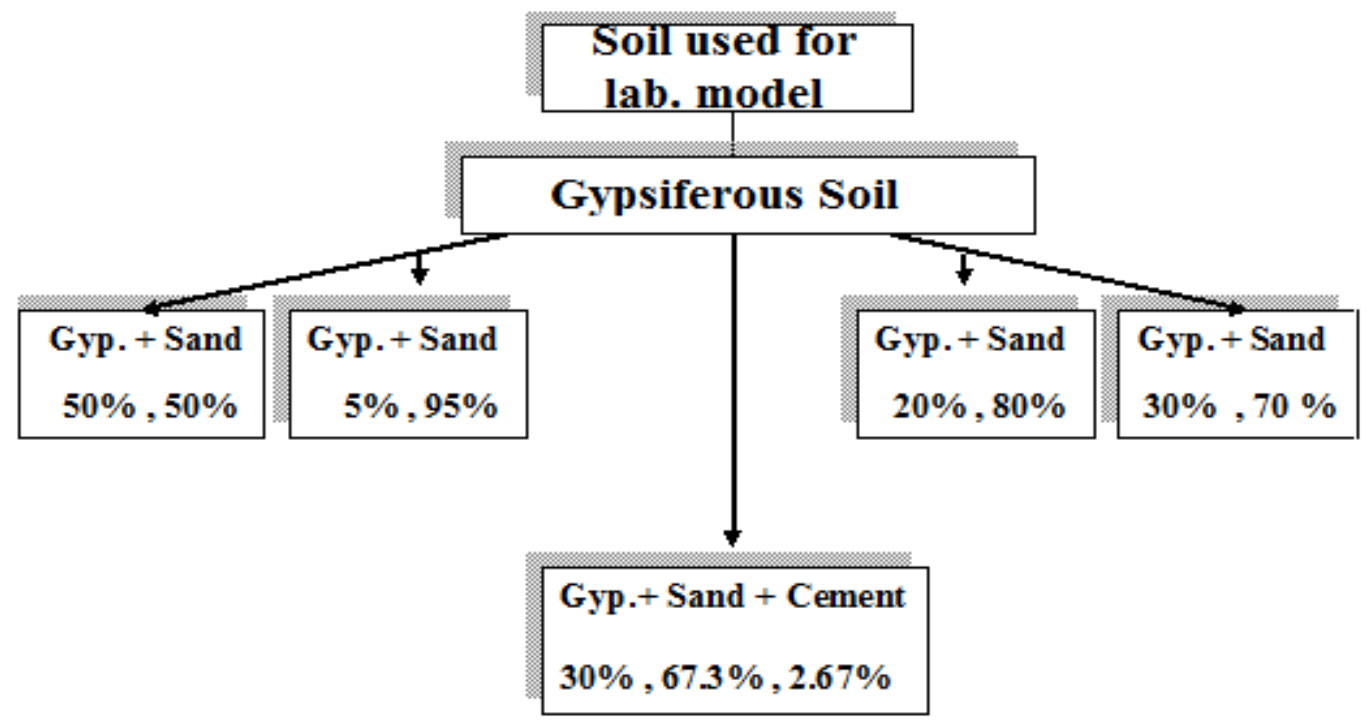

Fig. (1): The testing program for laboratory prototype.

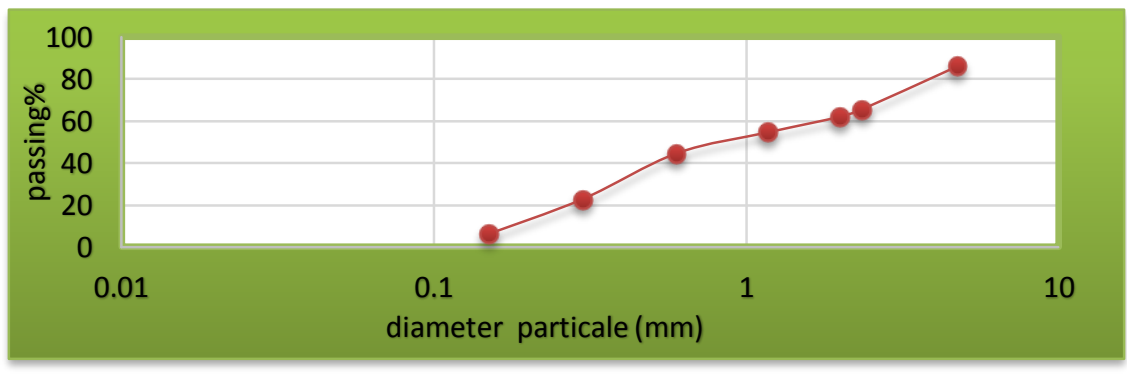

Fig. (2): Relationship between percentage passing and particle diameter for soil used.

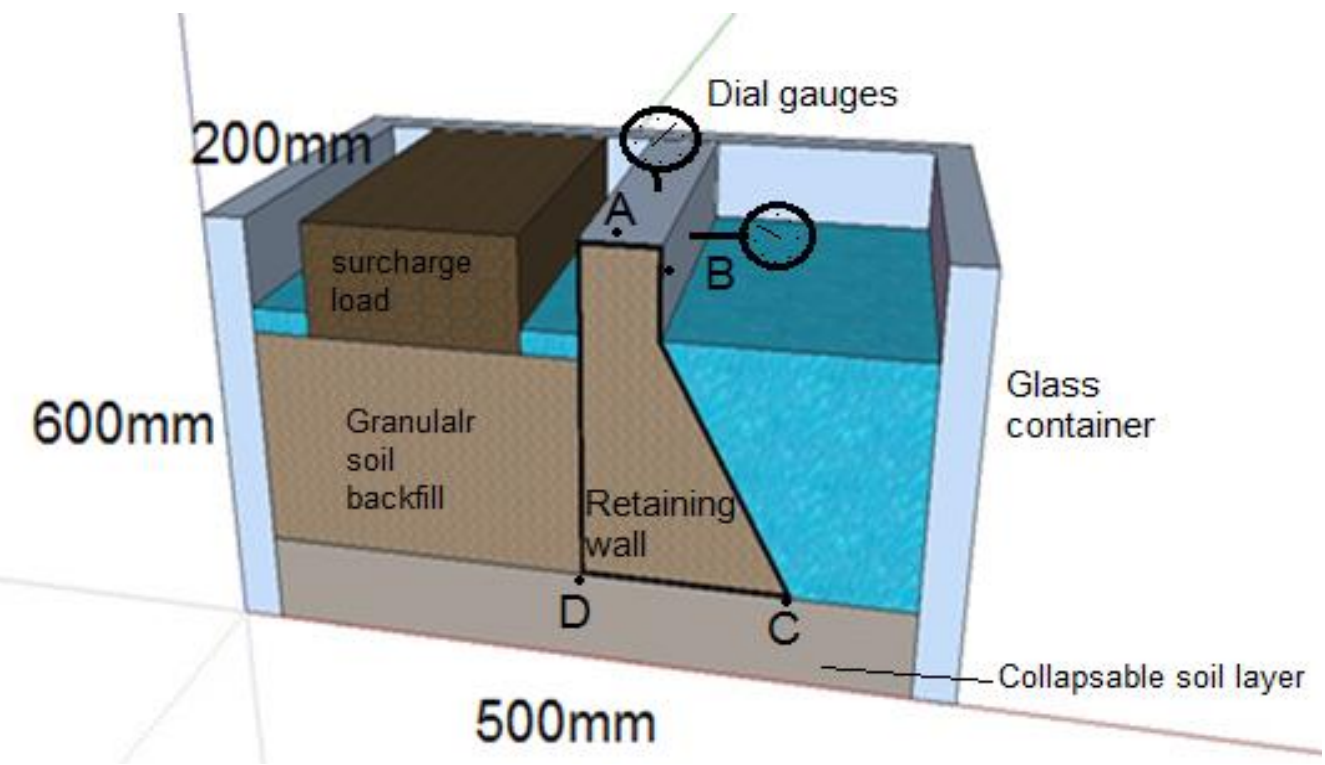

Fig (3): laboratory model retaining wall gypseous soil mode. 


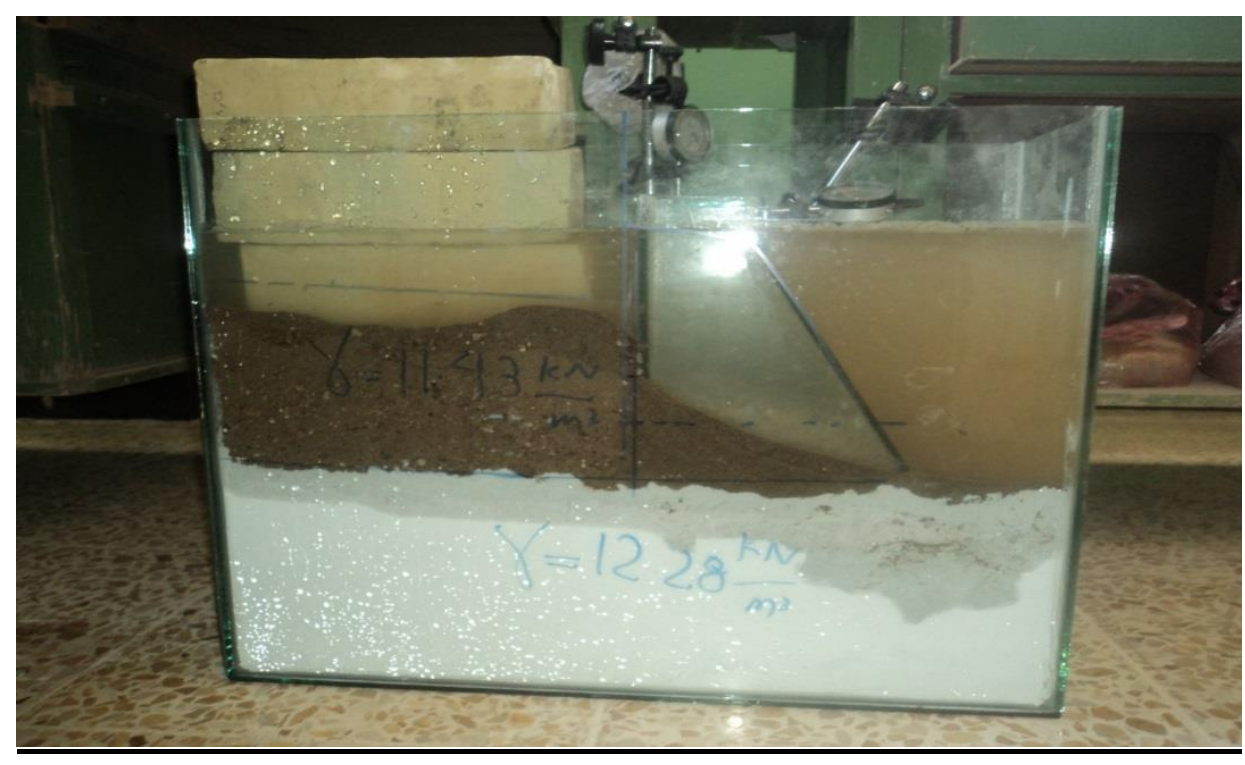

Fig (4): laboratory model retaining wall resting on gypseous soil.

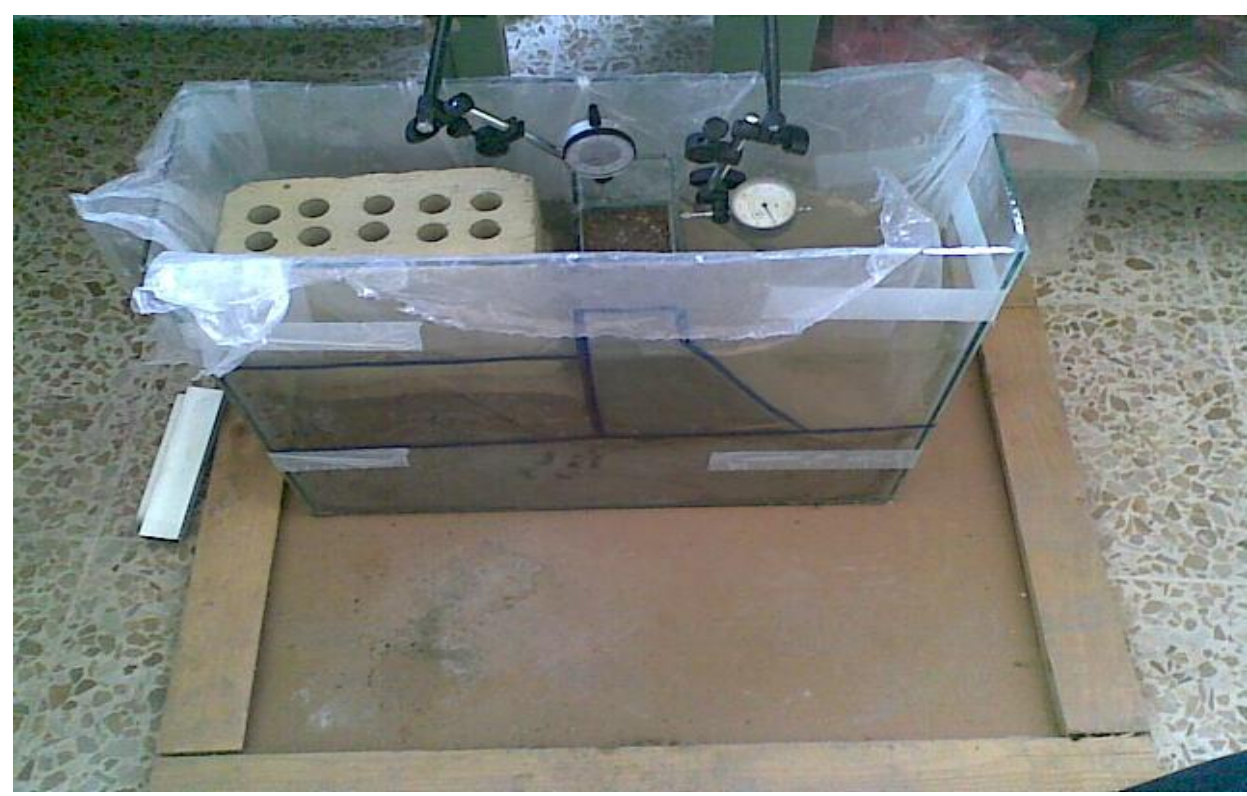

Fig (5): $200 \mathrm{~mm} * 600 \mathrm{~mm} * 500 \mathrm{~mm}$ glass model containing more than $40 \mathrm{~kg}$ of soil inside it placement over wooden plate. 


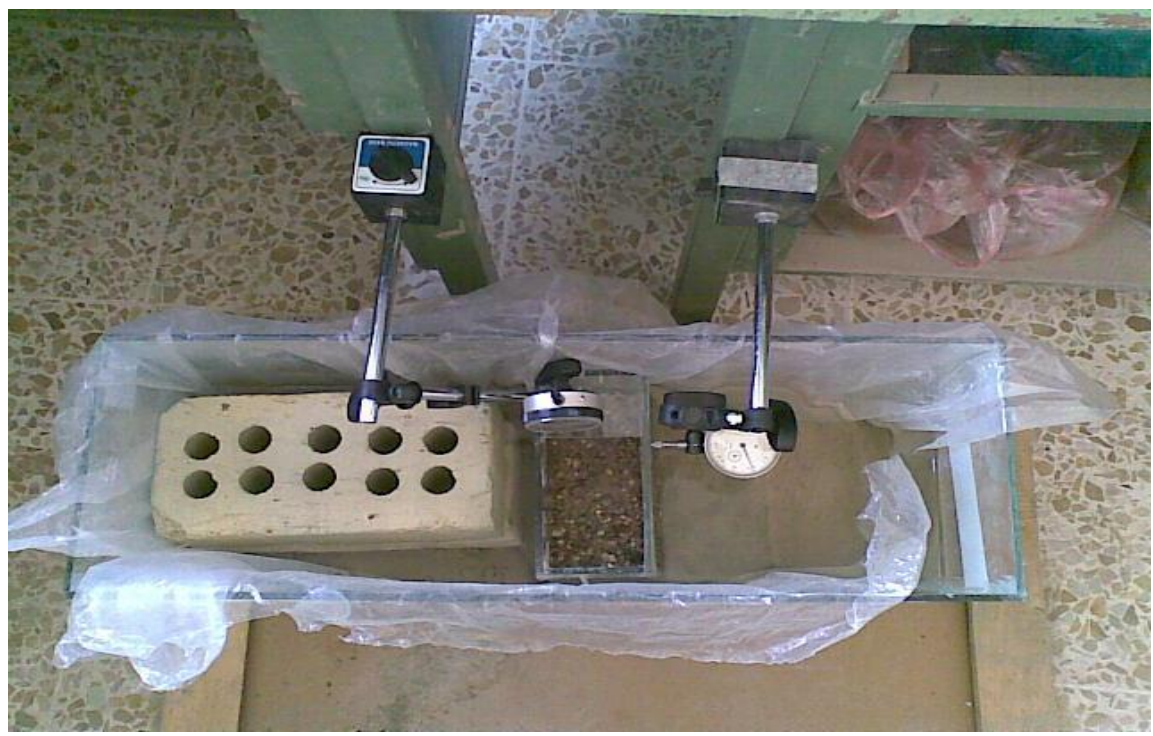

Fig (6): Gypseous soil bed placed, and then the glass gravity retaining wall placed over it with fitting vertical and lateral dial gauges.

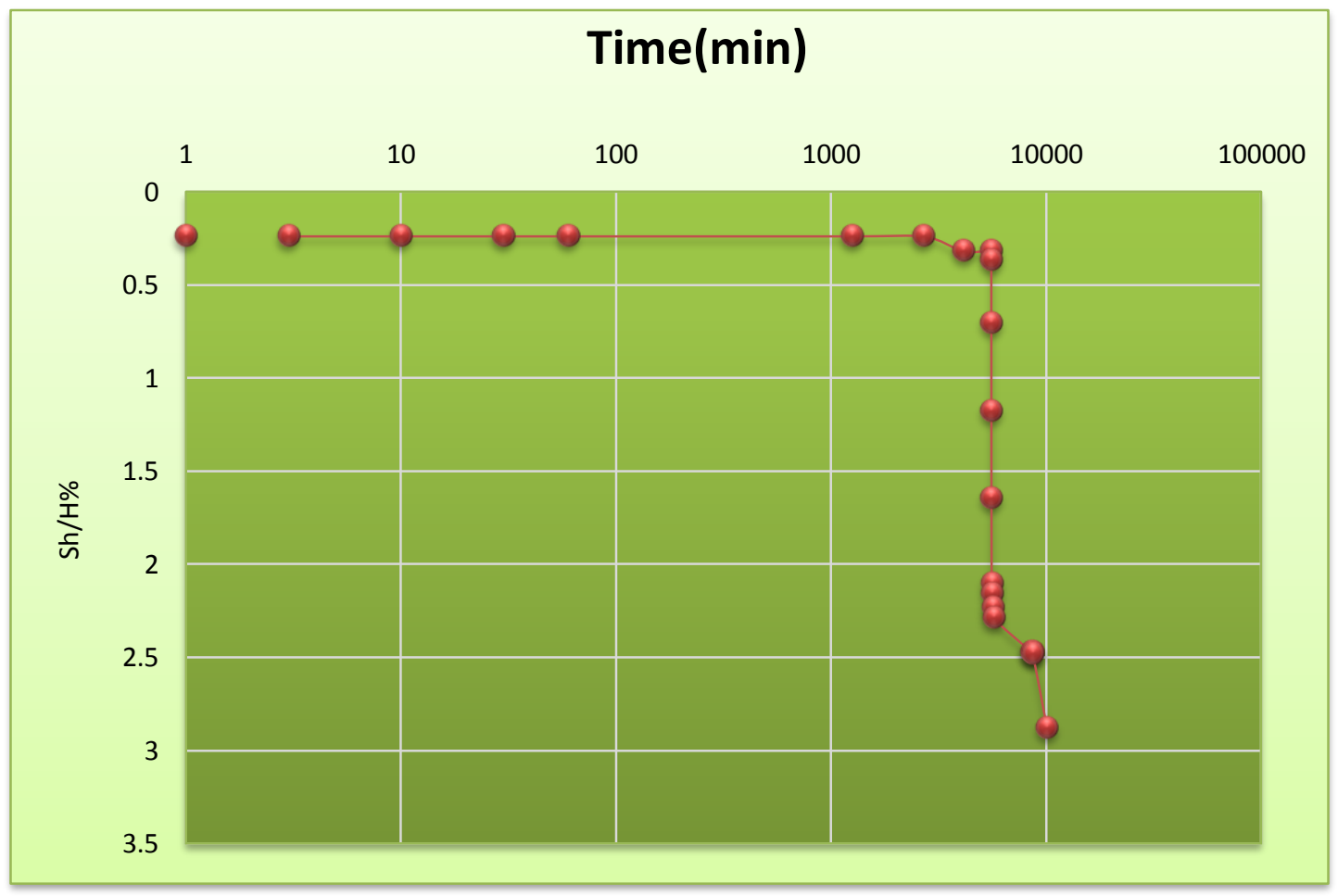

Fig. (7): Time - Settlement relationship for retaining wall model embedded with 50\% gyp. Soil layer (horizontal strain). 


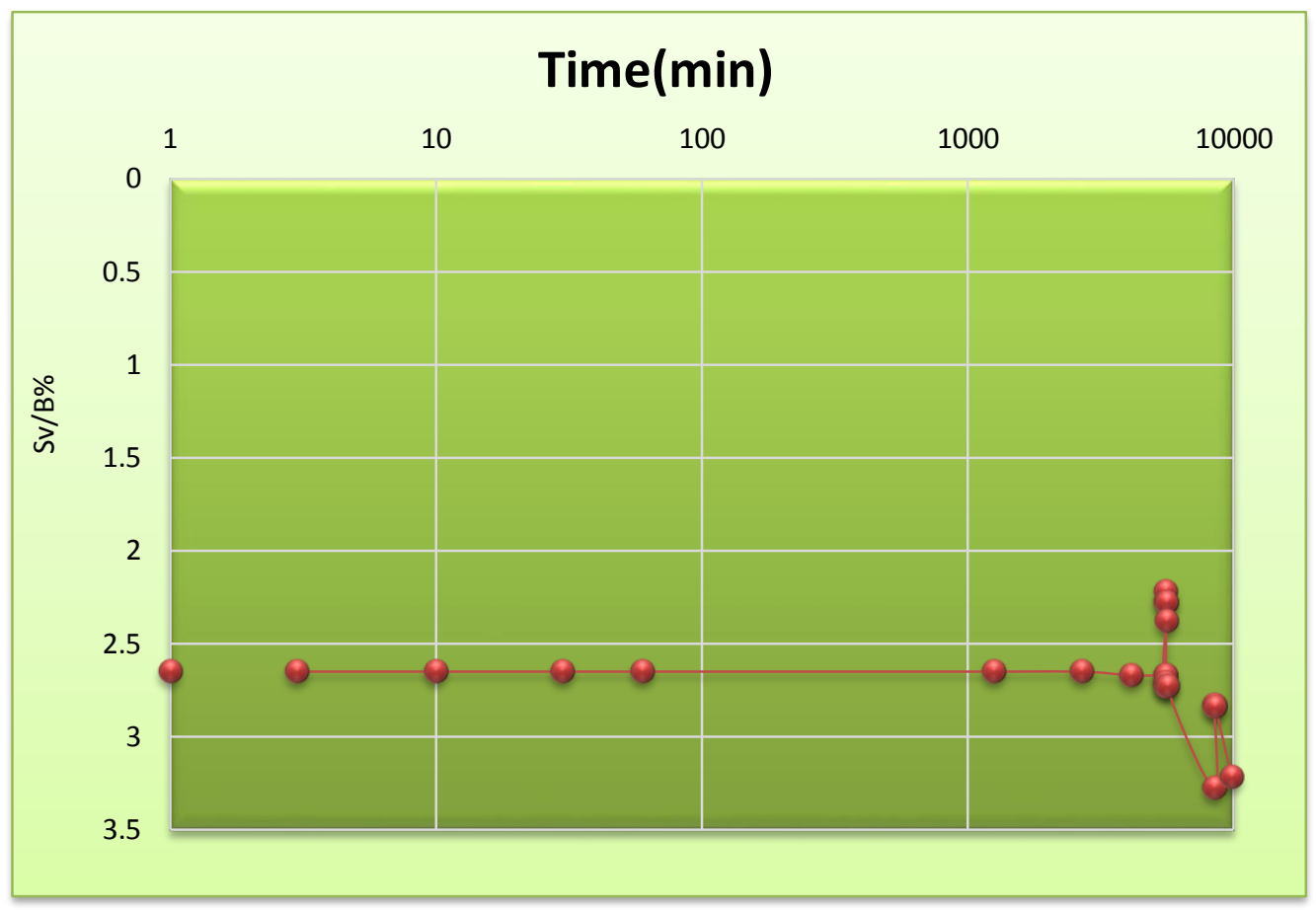

Fig. (8): Time - Settlement relationship for retaining wall model embedded with $50 \%$ gyp. Soil layer (vertical strain).

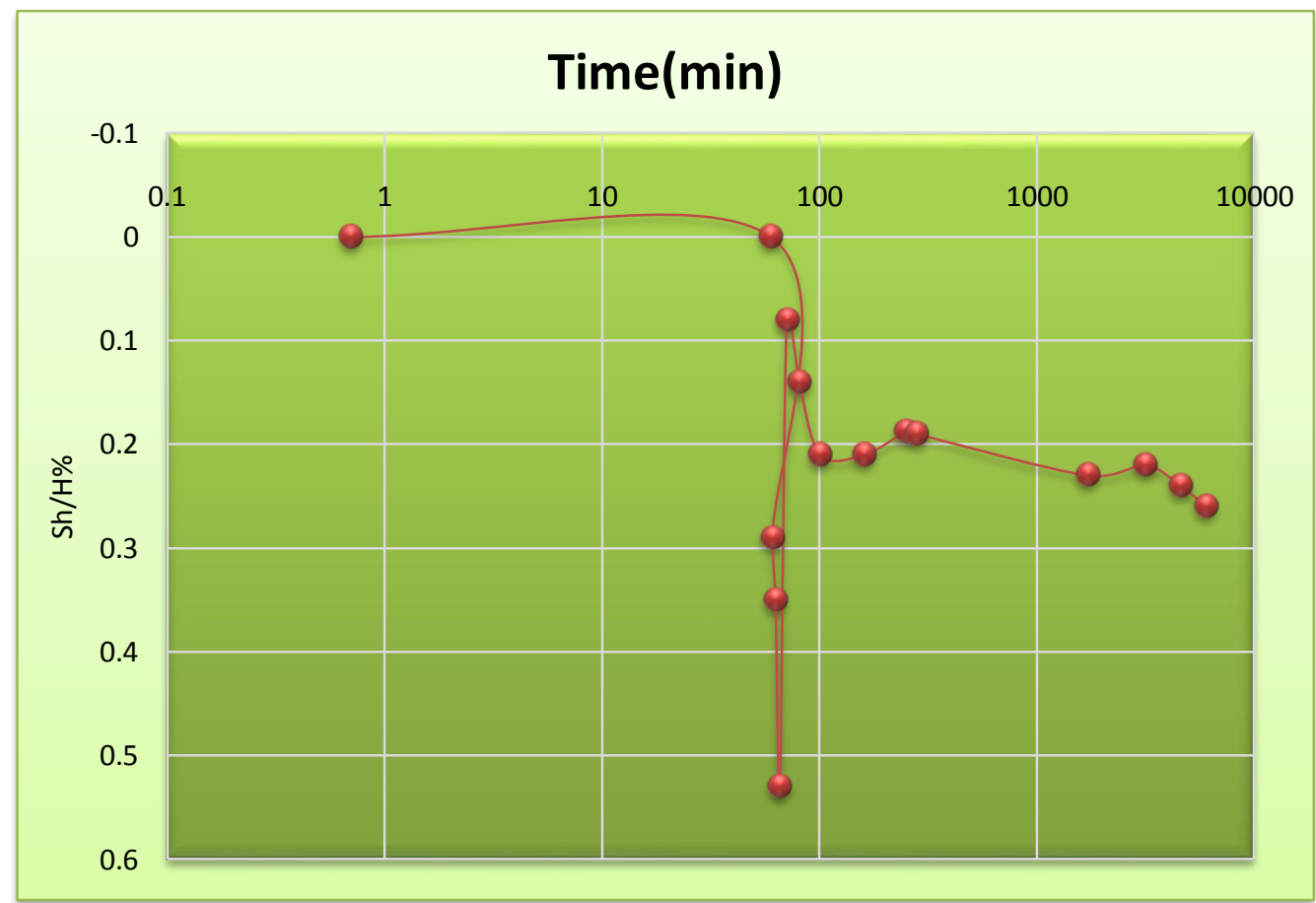

Fig. (9): Time-Settlement relationship for retaining wall model embedded with 5\% gyp. Soil layer (horizontal strain). 


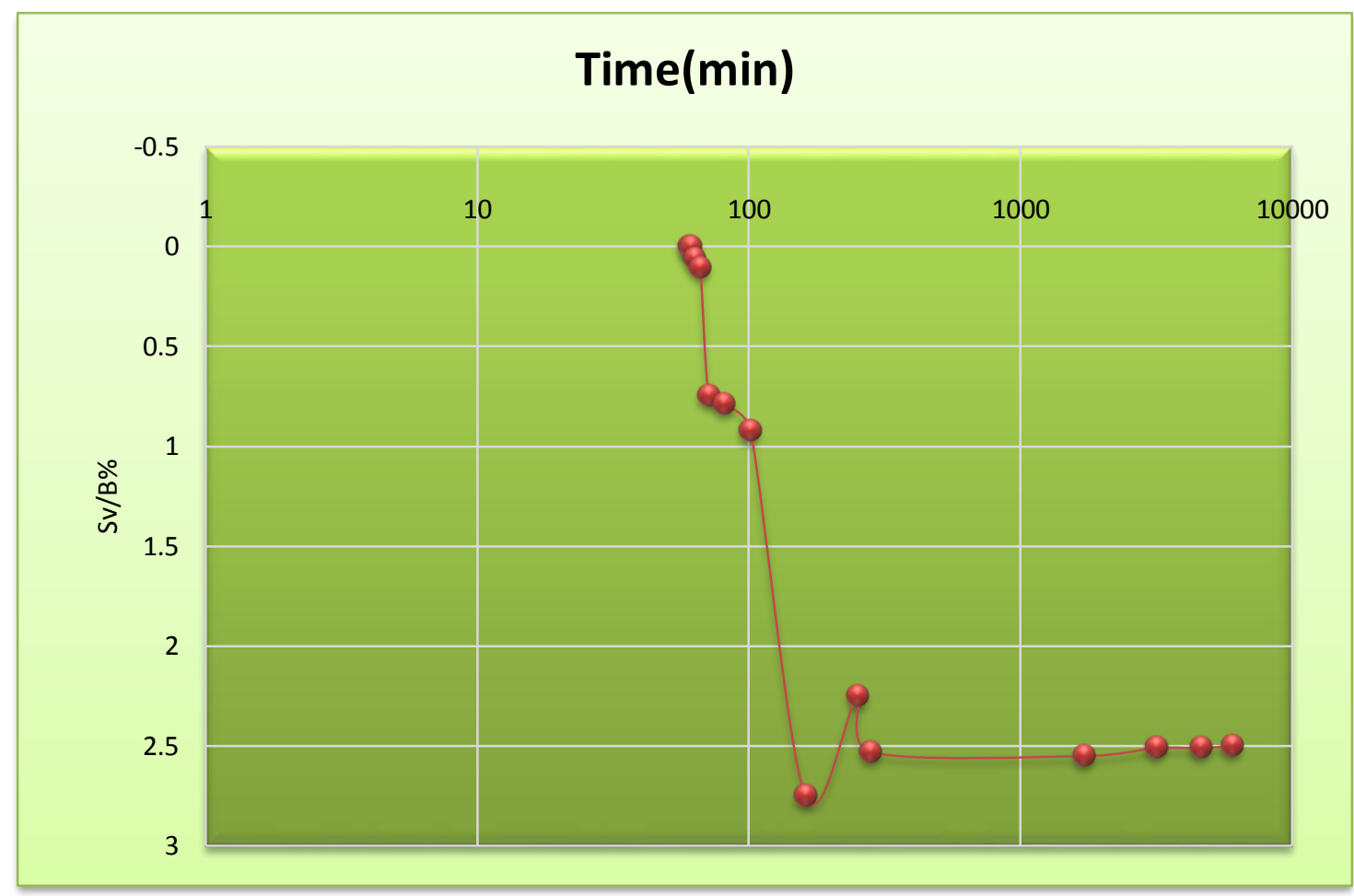

Fig. (10): Time - Settlement relationship for retaining wall model embedded with 5\% gyp. Soil layer (vertical strain).

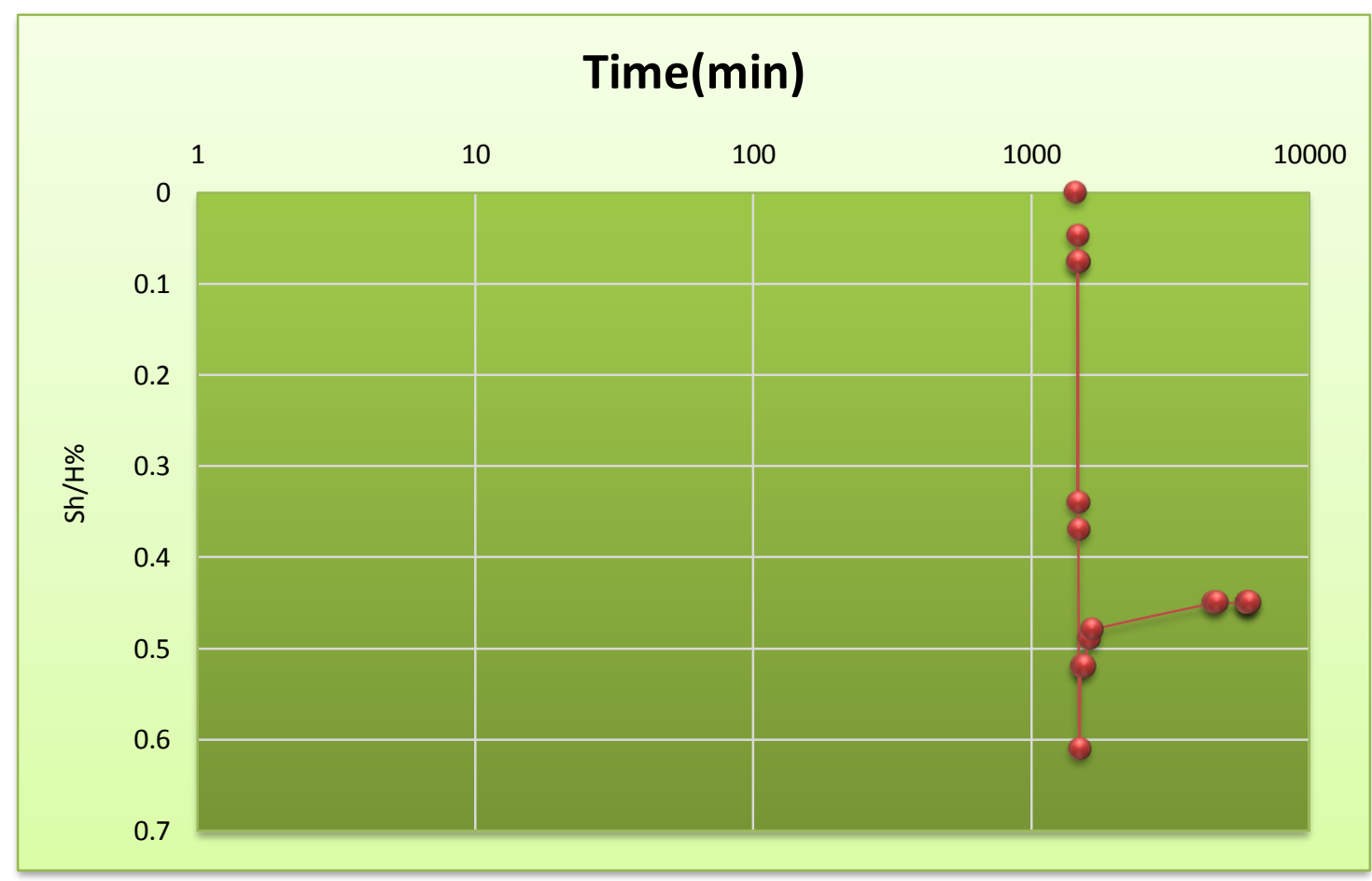

Fig. (11): Time \& Settlement relationship for retaining wall model embedded with $20 \%$ gyp. Soil layer (horizontal strain). 


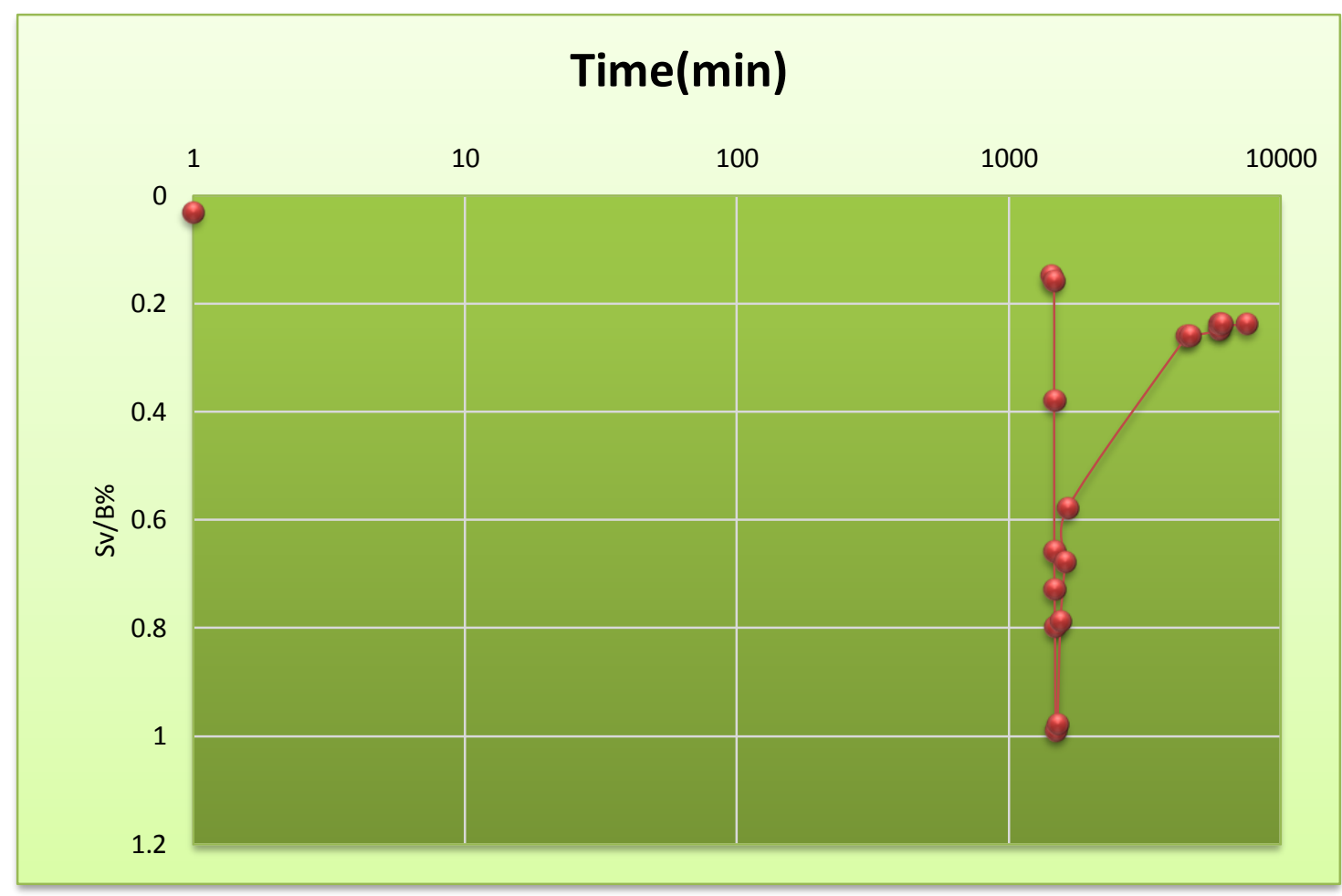

Fig. (12): relationship between time \& settlement for retaining wall model embedded with $20 \%$ gyp. Soil layer (vertical strain).

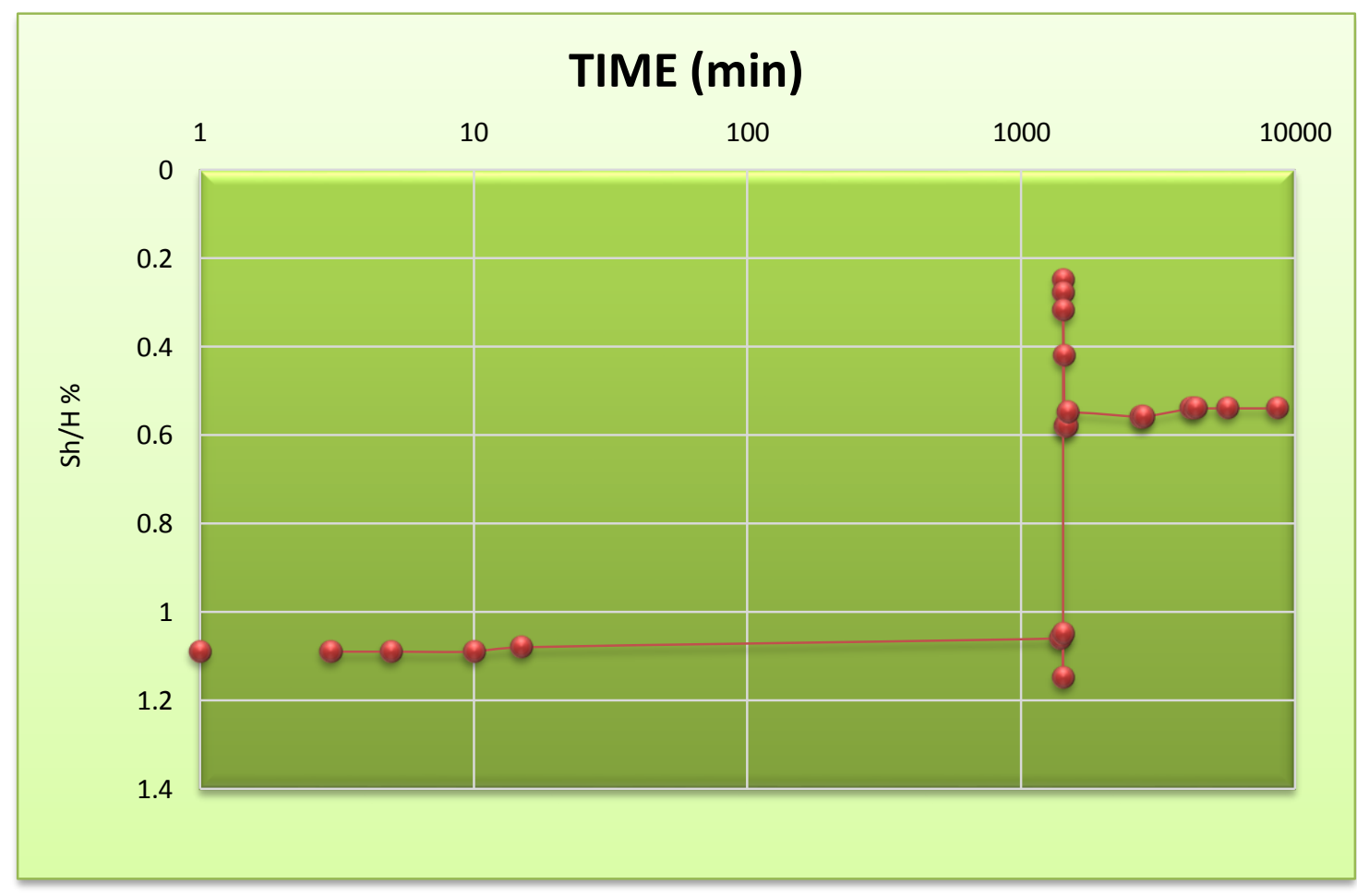

Fig. (13): Time \& Settlement relationship for untreated retaining wall model embedded with $30 \%$ gyp. Soil layer (horizontal strain). 


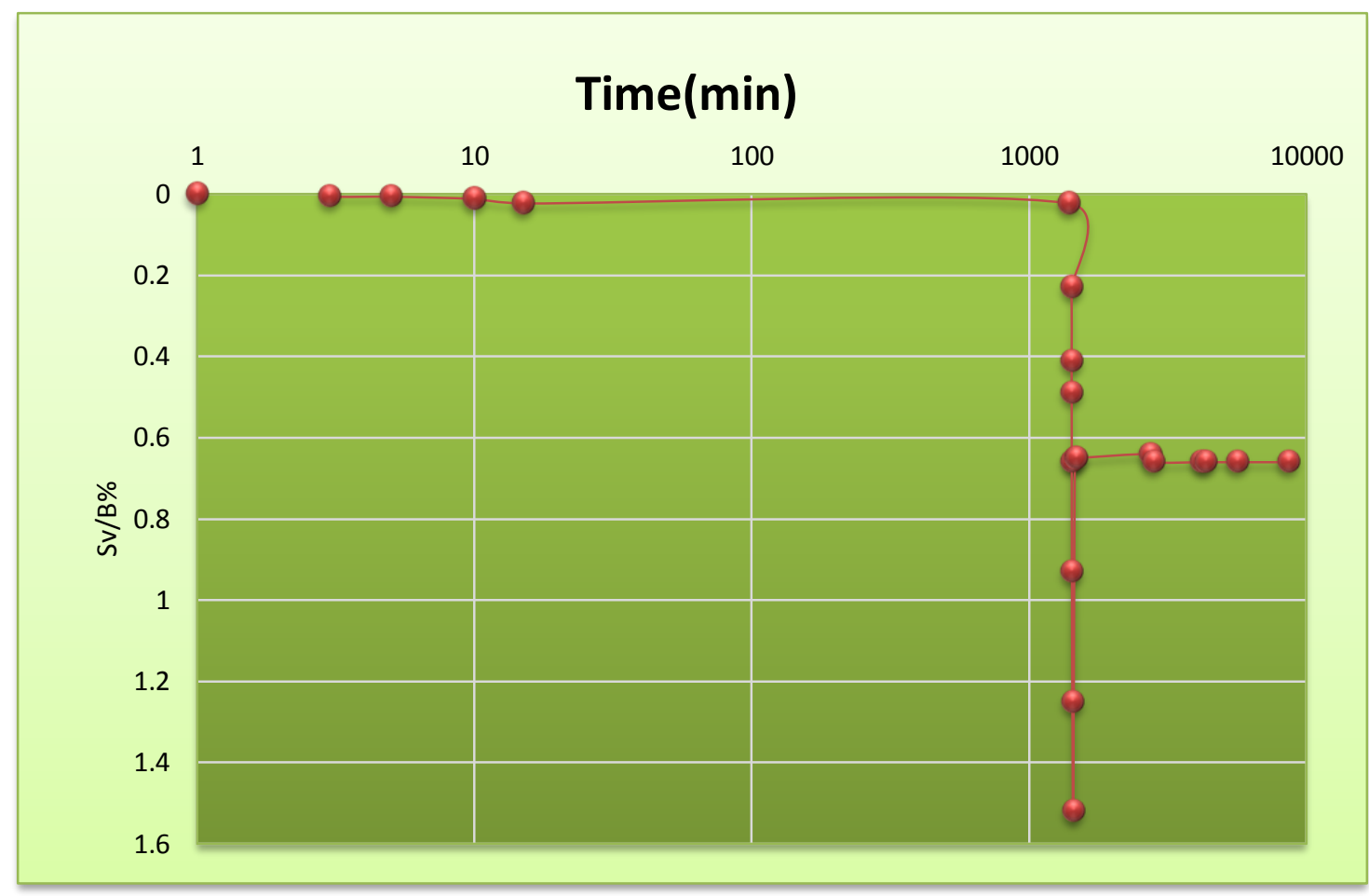

Fig. (14): Time \& Settlement relationship for untreated retaining wall model embedded with $30 \%$ gyp. Soil layer (vertical strain).

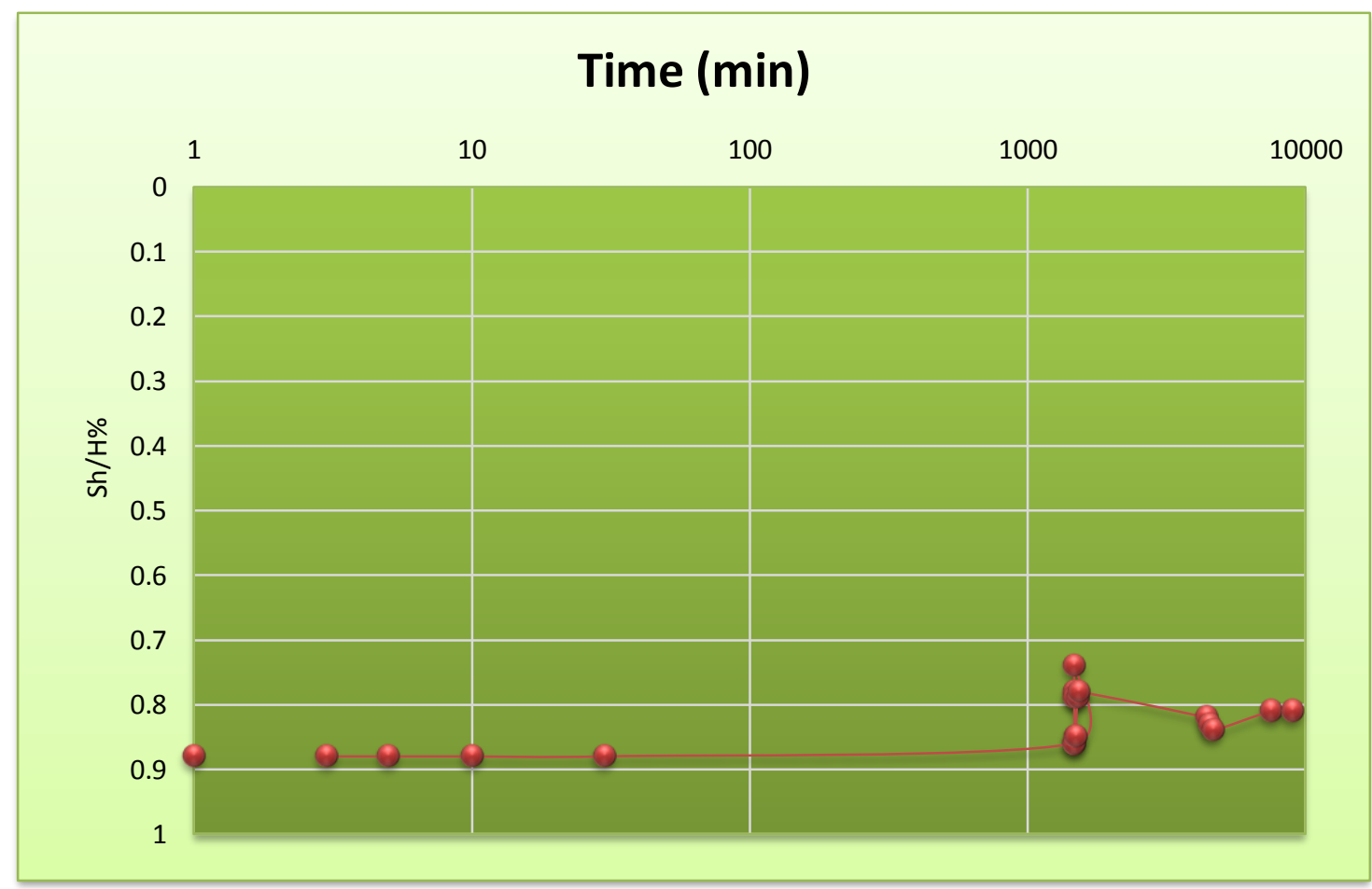

Fig. (15): Time \& Settlement relationship for retaining wall embedded with treated gyp. Soil layer with $(2.67 \%)$ cement adding by weight. (Horizontal strain) 


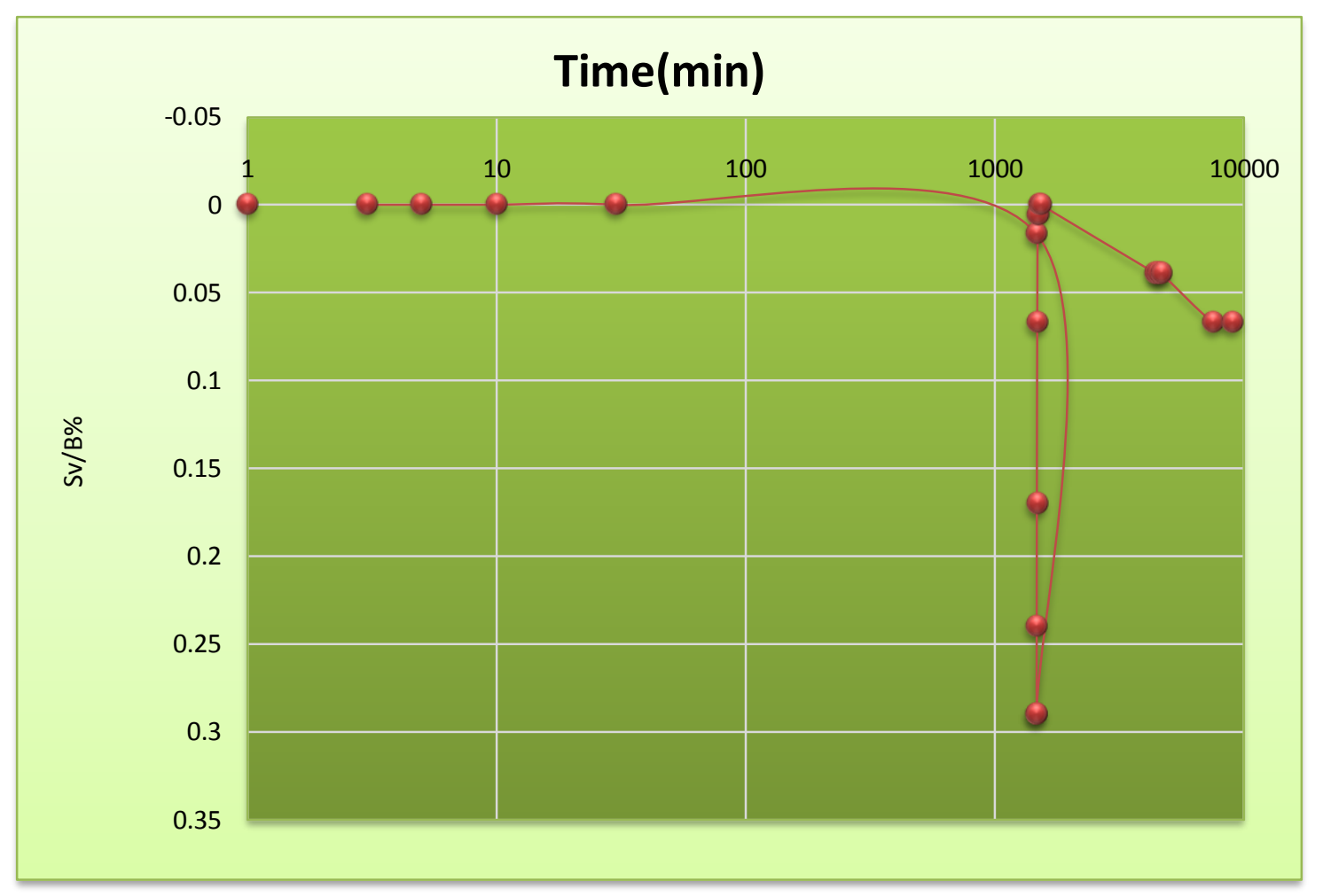

Fig. (16): Time \& Settlement relationship for retaining wall embedded by treated gyp. Soil layer with $(2.67 \%)$ cement adding by weight (vertical strain).

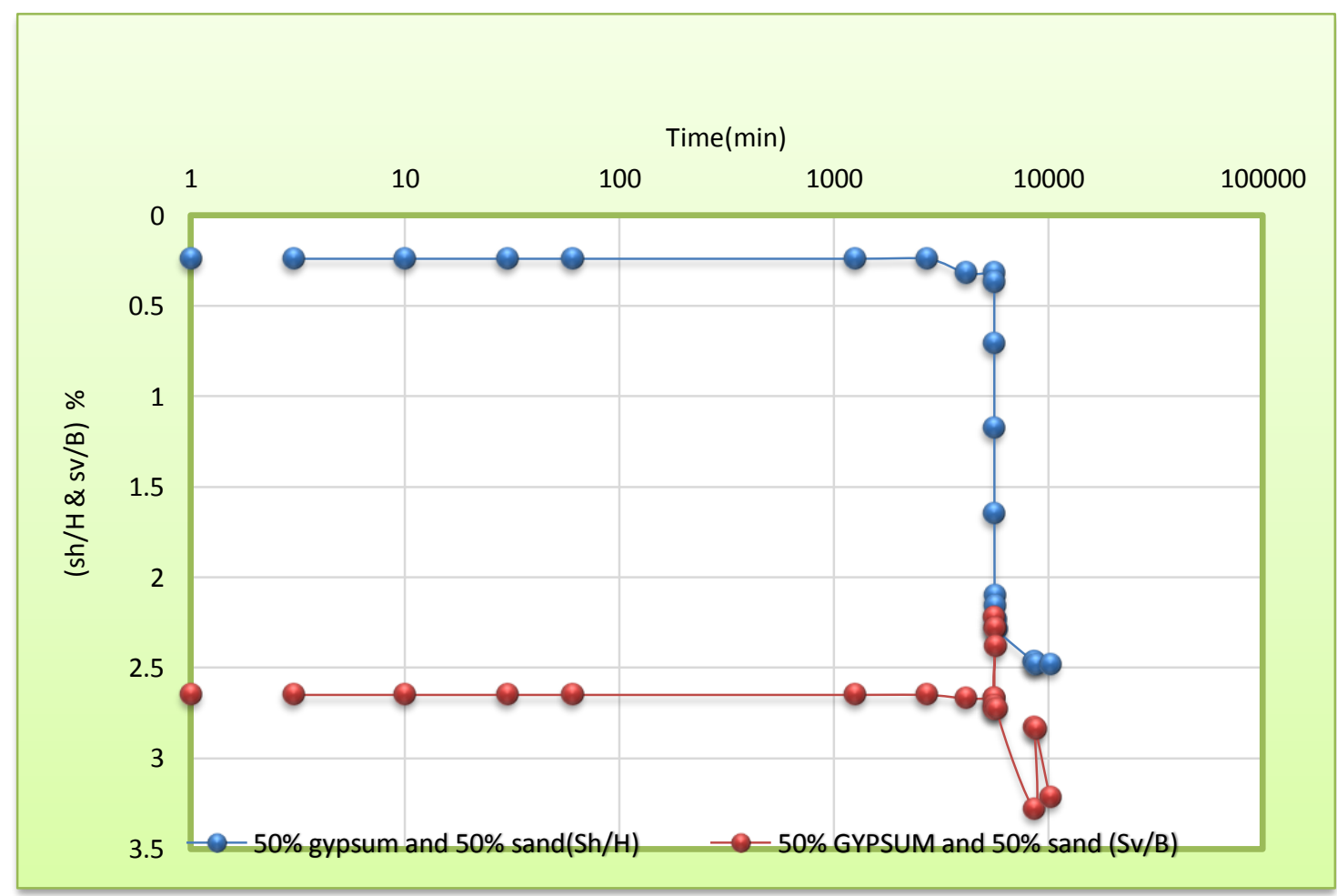

Fig. (17): Behavior of gyp. Soil embedded below lateral earth retaining wall at dry and wet condition for adding (50\%) gypsum by weight. 


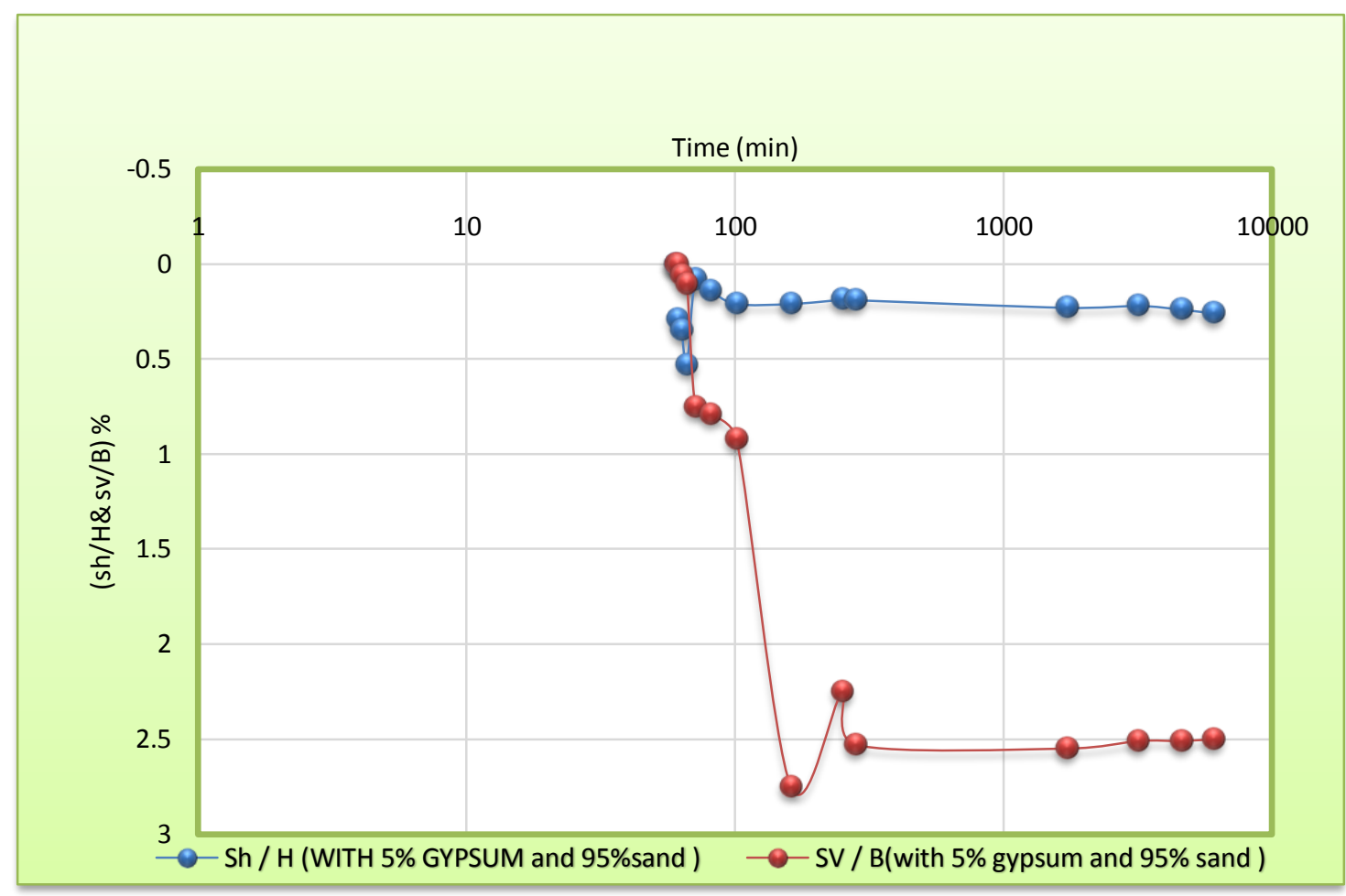

Fig. (18): Behavior of gyp. Soil embedded below lateral earth retaining wall at dry and wet condition for adding (5\%) gypsum by weight.

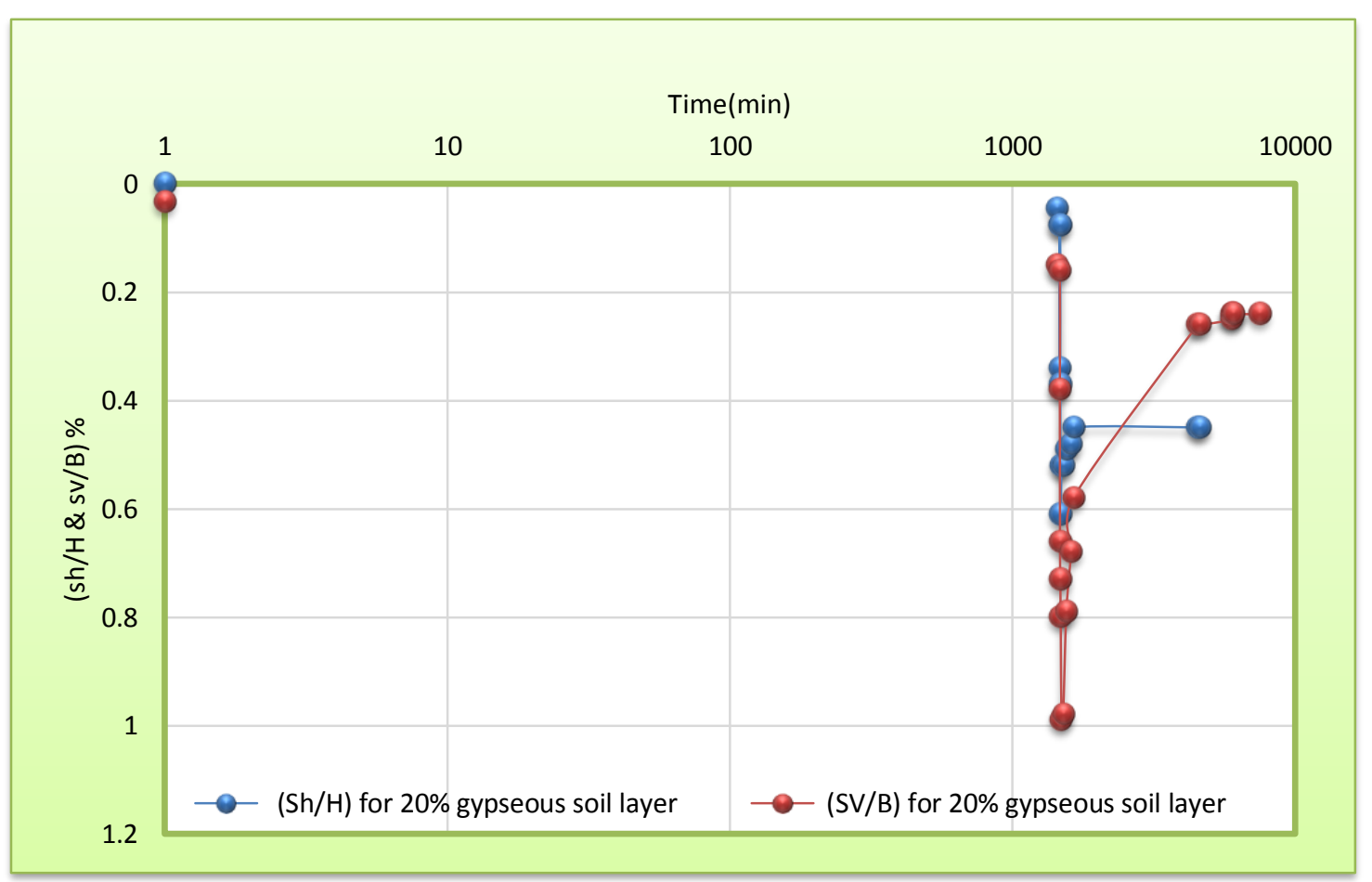

Fig. (19): Behavior of gyp. Soil embedded below lateral earth retaining wall at dry and wet condition for adding (20\%) gypsum by weight. 


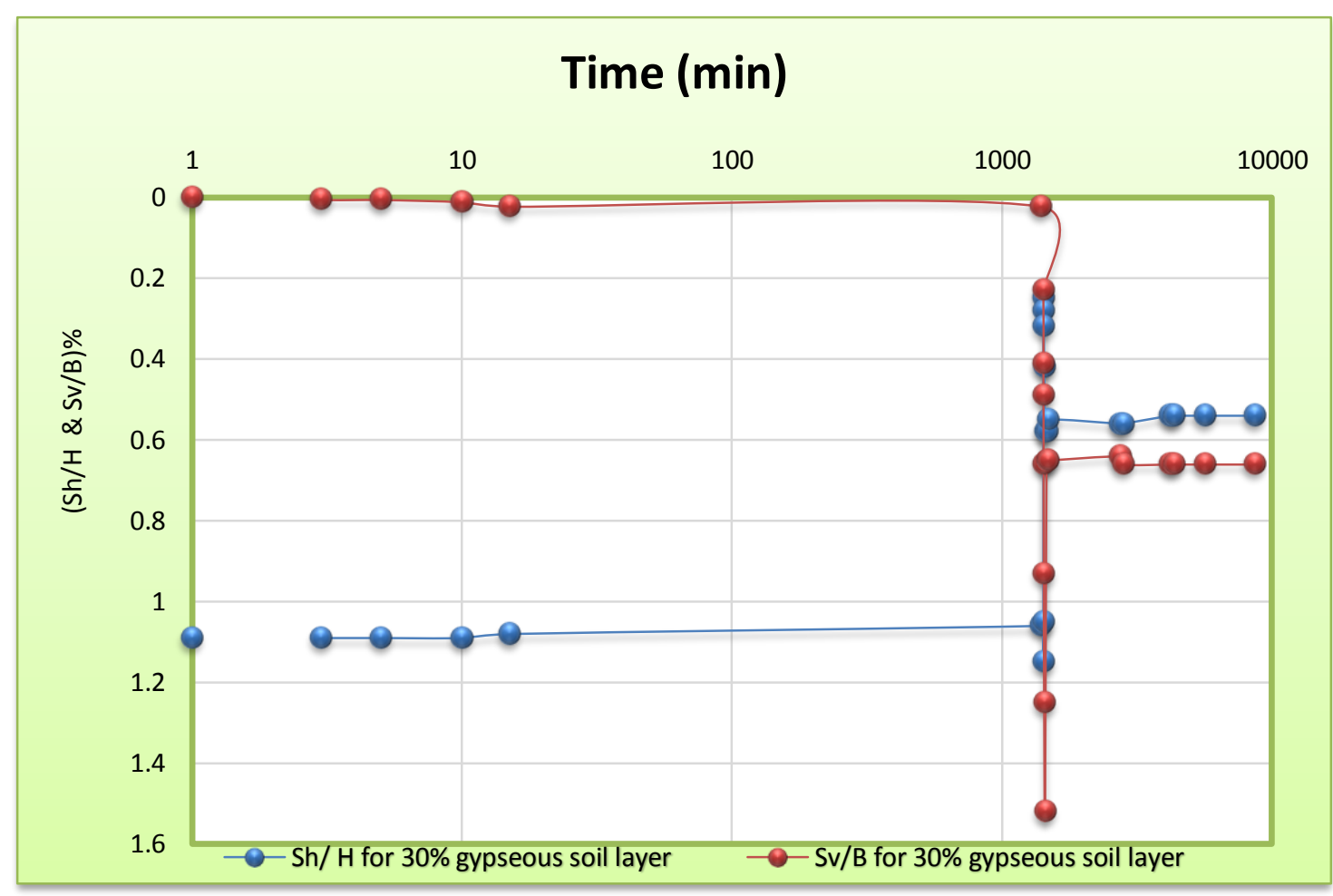

Fig. (20): Behavior of gyp. Soil embedded below lateral earth retaining wall at dry and wet condition. ((30\%) gypsum untreated gypseous soil bed).

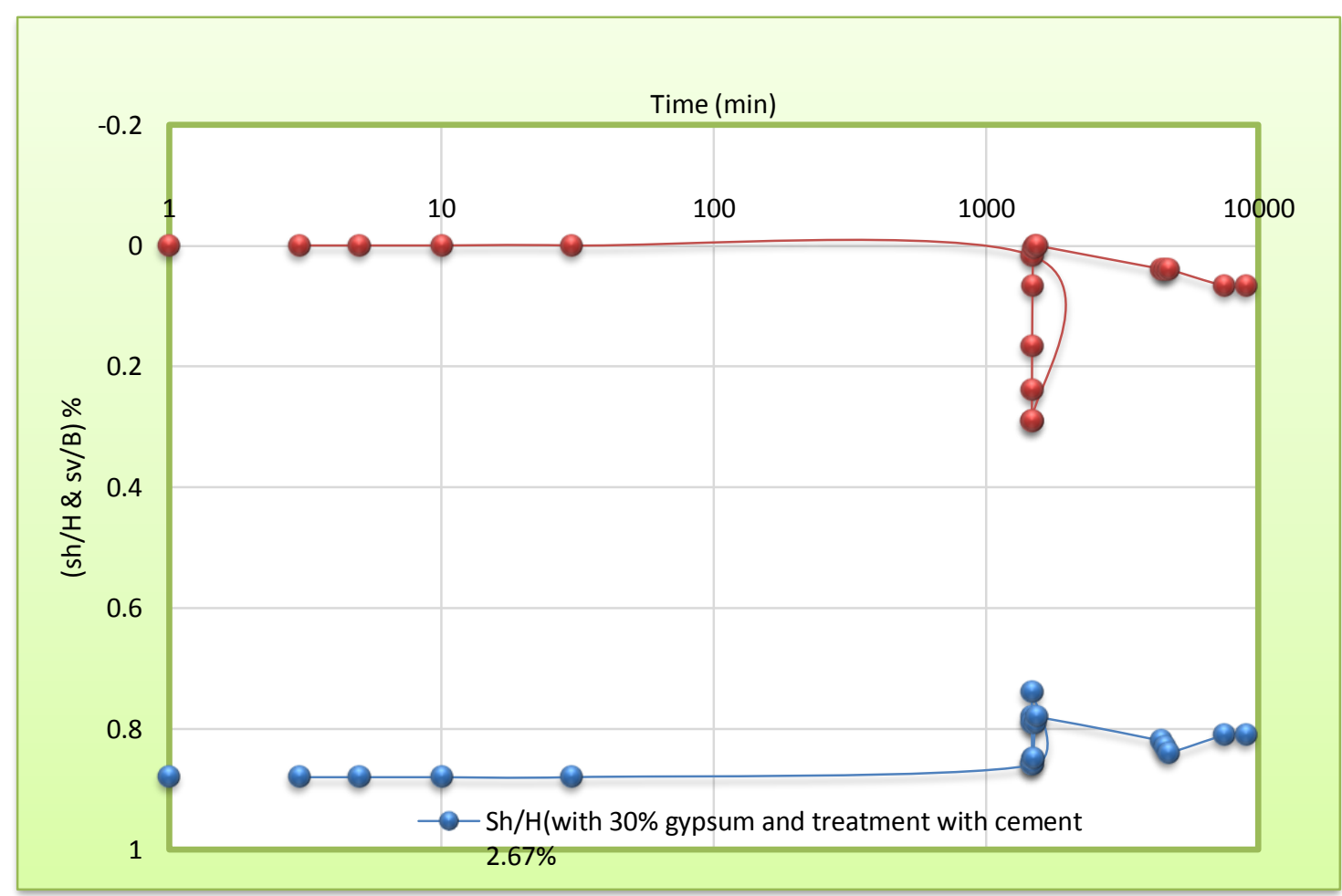

Fig. (21): Behavior of gyp. Soil embedded below lateral earth retaining wall at dry and wet condition (30\% gypseous soil treated with $(2.7 \%)$ cement addition). 


\title{
تصرف الجدران الساندة المقامة على ترب انهيارية- دراسة عملية على موديل مختبري
}

\author{
صفاء حسين عبد عون، وعد عبد الستار حسين

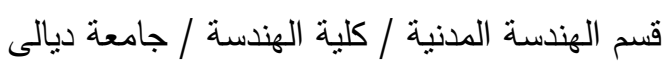

الخلاصة:

يتطلب استخدام الجدران الساندة في بعض المناطق التي تكثر فيها نسبة الجبس توخي الحذر. حيث ان تصرف هذه الجدران المقامة على ارض اعتيادية هو معروف. لكن تصرفها غير معروف عند احتواء التربة على نسب مختلفة من فئن

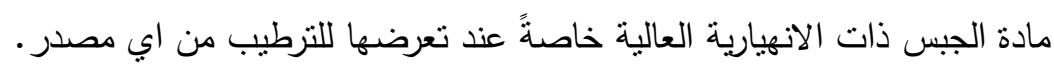

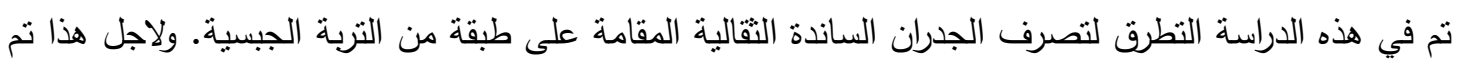

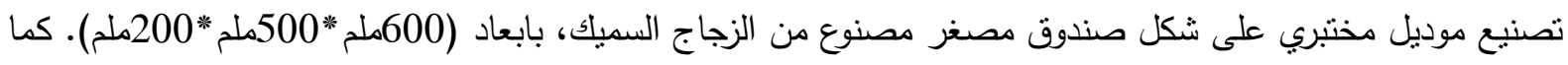

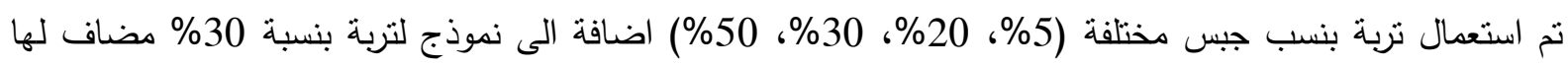
2.7 من مادة الاسمنت، توضع كطبقة تحت جدار ساند نم تصنيعة ايضا من الزجاج السميك المملوء بالرمل لتمثيل

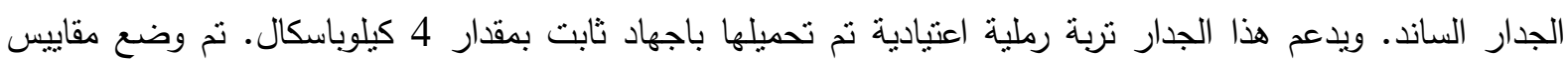

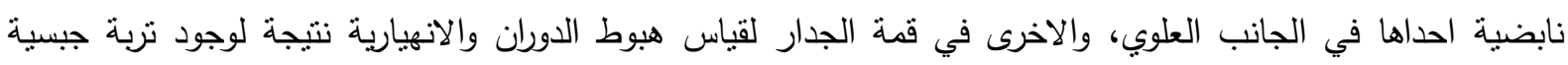

بعد تحليل النتائج للفحوص التي اجريت على النموذج المختبري. حيث اوضحت، ان تصرف الجدران الساندة

المقامة على هذه الترب من حيث الهبوط والدوران يختلف بشكل ملحوظ. كما واضهرت الدراسة ايضا ان التحسن في

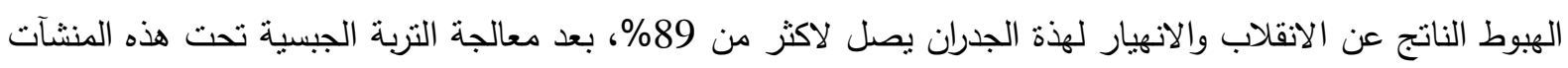
باضافة 2.7\% من مادة الاسمنت. مفاتيح الكلمات: الجدران الساندة, الترب الانهيارية، تصرف، مادة الاسينة معالجة. 